\title{
ArcheoSciences
}

Revue d'archéométrie

\section{Technological study of gold jewellery pieces dating from the Middle Kingdom to the New Kingdom in Egypt}

Étude technologique de pièces d'orfèvrerie datées du Moyen Empire au Nouvel Empire en Égypte

Lore G. Troalen, Maria Filomena Guerra, Jim Tate and Bill Manley

\section{OpenEdition}

\section{Journals}

Electronic version

URL: http://journals.openedition.org/archeosciences/2095

DOI: 10.4000/archeosciences.2095

ISBN: 978-2-7535-1598-7

ISSN: 2104-3728

Publisher

Presses universitaires de Rennes

\section{Printed version}

Date of publication: 31 December 2009

Number of pages: 111-119

ISBN: 978-2-7535-1181-1

ISSN: $1960-1360$

\section{Electronic reference}

Lore G. Troalen, Maria Filomena Guerra, Jim Tate and Bill Manley, « Technological study of gold jewellery pieces dating from the Middle Kingdom to the New Kingdom in Egypt », ArcheoSciences [Online], 33 | 2009, Online since 10 December 2012, connection on 30 April 2019. URL : http:// journals.openedition.org/archeosciences/2095; DOI : 10.4000/archeosciences.2095 


\title{
Technological study of gold jewellery pieces dating from the Middle Kingdom to the New Kingdom in Egypt
}

\author{
Étude technologique de pièces d'orfêvrerie datées du Moyen Empire \\ au Nouvel Empire en Égypte
}

\author{
Lore G. Troalen*, Maria Filomena Guerra**, \\ Jim TATE* and Bill MaNLEY ${ }^{* * *}$
}

\begin{abstract}
This paper presents a technological study of items of Egyptian jewellery from the collections of the National Museums Scotland: a pendant from the $19^{\text {th }}$ century BC; objects from the $16^{\text {th }}$ century BC royal burial unearthed at Qurneh; two gold finger-rings dated to the $14^{\text {th }}$ century BC; and a group of pendants from the $13^{\text {th }}$ century BC. The objects were examined using optical microscopy, X-radiography and Scanning Electron Microscopy (SEM). In addition, the elementary compositions of alloys and solder joints were investigated using air-path X-ray fluorescence (XRF), proton-induced X-ray analysis (micro-PIXE), and energy-dispersive X-ray analysis (SEM-EDS). This preliminary study provides information about the evolution of alloy composition and the use of alluvial gold, and illustrates the Ancient Egyptian goldsmiths' skills in working with wires, granulation and joining techniques.
\end{abstract}

Résumé : Cet article présente l'étude technologique de pièces égyptiennes d'orfevrerie faisant partie de la collection des musées nationaux d'Écosse : un pendentif daté du XIX siècle av. J.-C., des pièces d'orfevrerie provenant de la tombe royale de Qurneh datées du XVI siècle av. J.-C., deux bagues datées du $X I V$ siècle av. J.-C. ainsi qu'un groupe de pendentifs datés du XIII siècle av J.-C. Les objets ont été observés sous microscopie optique, par radiographie de rayons-X et par microscopie électronique à balayage en mode électron secondaire (MEB-SE). En parallèle, la composition des alliages et des soudures a été déterminée par fluorescence des rayons-X (FX), par analyse par faisceaux d'ions (micro-PIXE) et par énergie dispersive de rayons-X (MEB-EDS). Cette étude préliminaire donne des informations sur l'évolution des alliages ainsi que sur l'utilisation d'or alluvionnaire, et illustre les techniques utilisées par les orfevres de l'Egypte Ancienne, en particulier l'utilisation du filigrane, de la granulation et des techniques de soudure.

Keywords: Goldwork, Egypt joining, base-alloys, NMS.

Mots-clés : Orfevrerie, Egypte, soudures, alliages, NMS.

\footnotetext{
* National Museums Scotland, Department of Conservation \& Analytical Research - 242 West Granton Road, Edinburgh EH5 1JA. (l.troalen@nms. ac.uk and j.tate@nms.ac.uk)

** Laboratoires du Centre de Recherche et de Restauration des Musées de France, UMR171 CNRS - 14, quai François Mitterrand, 75001 Paris, France. (maria.guerra@culture.gouv.fr)

*** National Museums Scotland, Department of World Cultures, - Chambers Street, Edinburgh EH1 1JF. (b.manley@nms.ac.uk)
} 


\section{INTRODUCTION}

Numerous works on jewellery originating from Ancient Egypt are conveniently cited in studies by Lucas (1929, reedited 1962), Ogden (1982; 2000) and Andrews (1990). However, relatively little work is available combining elemental analysis with technological study; the principal exceptions are Lucas (1962) and Schorsch (1995) on jewellery from the burial of Wah, and Lilyquist (2003) on jewellery from the burial of the foreign wives of Thutmose III, while others are cited by Schorsch (2001). As a result, little is known about the alloys used in Ancient Egypt, or about manufacturing techniques such as filigree and granulation. In order to shed more light on this technology, we applied a multi-disciplinary approach to the analysis of several artefacts in the collections of National Museums Scotland (NMS).

NMS holds about 6,000 objects from Ancient Egypt and Sudan, including gold and electrum jewellery that has hitherto not been the subject of significant scientific study. The collections cover all periods from the Predynastic to the Roman Empire, and a good proportion of the artefacts derive from reputable archaeological excavations carried out during the $19^{\text {th }}$ and $20^{\text {th }}$ centuries. An example of this is the intact royal burial from Qurneh, near Thebes, acquired by the former Royal Scottish Museum (a precursor of NMS) in 1909 , and dated to the $16^{\text {th }}$ century BC. The Qurneh burial included the ornately decorated coffin and mummy of a young adult woman and the simpler coffin and mummy of a child (Petrie, 1909), both of whom had been buried with a range of grave goods, including jewellery of gold, electrum, ivory and faience (Eremin et al., 2000; Manley et al., 2002). In addition to the gold necklace described elsewhere in this volume (Tate et al., 2010), the woman was provided with: four gold bracelets made from a $\mathrm{D}$-section bar bent into a ring and soldered (A.1909.527.16 + A-C); an electrum girdle consisting of twenty-six scaraboid beads and twelve barrel beads threaded on a double string (A.1909.527.17); and two gold earrings consisting of four penannular hoops soldered together (A.1909.527.18 + A). The child's mummy wore a simpler gold necklace (A.1909.527.11), and two loops, each consisting of three-and-a-half gold rings, which are usually described as earrings (A.1909.527.43+A).

To the purpose of carrying out an initial investigation into the varieties of alloys and production techniques used in Ancient Egypt, we studied the Qurneh jewellery along with a small collection of other gold items spanning the period between the $19^{\text {th }}$ and the $13^{\text {th }}$ centuries BC, containing: a fish-shaped pendant (A.1914.1081) from a tomb at
el-Harāgeh from the mid- $19^{\text {th }}$ century $\mathrm{BC}^{1}$; two gold fingerrings with decorated bezels (A.1883.49.2 + A.1883.49.8) from the Amarna royal tomb of the late $18^{\text {th }}$ Dynasty $\left(14^{\text {th }}\right.$ century BC); ${ }^{2}$ and sixteen fly-shaped pendants (A.1977.140 A-P), assumed, on stylistic grounds, to date from the $19^{\text {th }}$ Dynasty $\left(13^{\text {th }} \text { century } \mathrm{BC}\right)^{3}$.

\section{MethodS}

The objects were examined at NMS using a stereomicroscope (Olympus SZX12 x 7-90) equipped with a digital camera (Olympus DP70) and CamScan Scanning Electron Microscopy in Secondary Electron mode (SEI), and their construction investigated using a $300 \mathrm{kV}$ Pantak $\mathrm{X}$-radiography system.

The elemental composition of the alloys was determined using an Oxford Instruments ED 2000 air-path X-ray fluorescence (XRF), with a Rhodium target X-ray tube collimated to a point of about $2 \times 1.5 \mathrm{~mm}$, coupled to a $\mathrm{Si}(\mathrm{Li})$ detector using the Oxford Xpert Ease software. In addition, proton-induced $3 \mathrm{MeV} \mathrm{X}$-ray analysis (micro-PIXE) was carried out at the external beamline of the AGLAE accelerator at the Centre de Recherche et de Restauration des Musées de France (Guerra and Calligaro, 2003; Dran et al., 2004; Guerra, 2008). Energy Dispersive X-ray analysis (SEM-EDS), using the Noran Vantage system and Vista software, was used to characterise inclusions of platinumgroup elements (PGE) and investigate other compositional information. All SEM-EDS measurements were performed at the analytical working distance of $35.0 \mathrm{~mm}$ at $300 \mathrm{~s}$ measurement with a voltage of $20 \mathrm{kV}$ or $25 \mathrm{kV}$.

Table 1 presents the compositional analysis of ternary alloys of gold-silver-copper standards, showing the interinstrument compatibility. The compositions of the objects can be found in Table 2, and are summarised in the ternary diagram in Fig. 3. For the Qurneh jewellery, all compositional results are from PIXE analysis, except for the girdle, which, like most of the jewellery, was analysed with XRF.

1. The pendant is $41 \mathrm{~mm}$ long by $19 \mathrm{~mm}$ high. It was excavated in the burial of a ten years old girl in Cemetery A/Tomb 72. Fish-shaped pendants, known as $n k h \bar{a}$, were usually worn by children or young women.

2. See Martin (1974, nos. 275 and 280). Dimensions: A.1883.49.2, diameter of hoop $28 \mathrm{~mm}$ (internal $16 \mathrm{~mm}$ ), bezel $12 \mathrm{~mm}$ by $13 \mathrm{~mm}$. A.1883.49.8, diameter of hoop $22 \mathrm{~mm}$, bezel $13 \mathrm{~mm}$ by $9 \mathrm{~mm}$.

3. The fly-pendants might have formed part of an official's usekh-collar, cf. an example in The Egyptian Museum, Cairo (CG 52677). The pendants are nearly identical and are $11 \mathrm{~mm}$ long by $7 \mathrm{~mm}$ high. 


\begin{tabular}{|c|c|c|c|c|}
\hline \multicolumn{2}{|c|}{ Standards NMS } & $\mathrm{Au} \%$ & $\mathrm{Ag} \%$ & $\mathrm{Cu} \%$ \\
\hline \multirow{6}{*}{ Rolled gold } & Theoretical Value & 80.0 & 10.0 & 10,0 \\
\hline & PIXE - 2 values & 80.0 & 10.7 & 9,3 \\
\hline & \multirow{2}{*}{$\begin{array}{l}\mathrm{XRF}-5 \text { values } \\
\text { standard deviation }\end{array}$} & 79.4 & 10.6 & 10,0 \\
\hline & & 0.3 & 0.3 & 0,1 \\
\hline & \multirow{2}{*}{$\begin{array}{l}\text { SEM-EDS - } 4 \text { values } \\
\text { standard deviation }\end{array}$} & 80.9 & 9.6 & 9,5 \\
\hline & & 0.9 & 0.7 & 0,3 \\
\hline \multirow{6}{*}{ GCS5 } & Theoretical Value & 80.0 & 17.1 & 2,9 \\
\hline & PIXE - 2 values & 79.4 & 17.9 & 2,7 \\
\hline & \multirow{2}{*}{$\begin{array}{l}\text { XRF - } 5 \text { values } \\
\text { standard deviation }\end{array}$} & 78.5 & 18.6 & 3,0 \\
\hline & & 0.5 & 0.4 & 0,1 \\
\hline & \multirow{2}{*}{$\begin{array}{l}\text { SEM-EDS - } 3 \text { values } \\
\text { standard deviation }\end{array}$} & 79.2 & 17.9 & 2,9 \\
\hline & & 1.1 & 1.4 & 0,4 \\
\hline \multirow{3}{*}{ GCS4 } & Theoretical Value & 61.9 & 35.1 & 3.0 \\
\hline & \multirow{2}{*}{$\begin{array}{l}\text { XRF - } 8 \text { values } \\
\text { standard deviation }\end{array}$} & 61.4 & 35.6 & 3.0 \\
\hline & & 0.7 & 0.8 & 0.1 \\
\hline \multirow{3}{*}{ GCS7 } & Theoretical Value & 45.0 & 39.8 & 15.2 \\
\hline & \multirow{2}{*}{$\begin{array}{l}\text { XRF - } 6 \text { values } \\
\text { standard deviation }\end{array}$} & 44.5 & 40.0 & 15.5 \\
\hline & & 0.1 & 0.2 & 0.3 \\
\hline
\end{tabular}

decoration, and deformations of the edges of the beads and of holes in the wallet spacers where they sit against the beads (Fig. 1a). Occasionally, some small barrel beads are trapped within wallet beads (Fig. 1b). For the finger-ring, we observed that the granules on the bezel are flattened, except those immediately beside the bezel hole, which remain perfectly spherical (see Fig. 5).

\section{Gold Alloys}

We observed and analysed PGE inclusions, ranging from a few to a few hundred microns in diameter, in all the jewellery items except the fly-pendants. PGE inclusions are characteristic for gold from alluvial deposits (Ogden, 1976), and can be found in all the Qurneh objects. However, only a single inclusion was found in the woman's earrings, and a single small inclusion was found in the tail of the fishpendant (Fig. 2a). By comparison, the Amarna finger-rings contain numerous inclusions, which may indicate the use of gold from other deposits. The inclusions show a range of composition, with an average of $36 \%$ iridium, $42 \%$ osmium and $22 \%$ ruthenium, corresponding well with compositions reported by Meeks and Tite (1980) in their investigation of Egyptian objects from the British Museum, and also with the range otherwise expected for Egyptian deposits (Ahmed, 2007). We also observed variable ratios of iridium, osmium and ruthenium in the PGE inclusions within the same object, making the formulation of any conclusions regarding the gold deposits difficult. However, the absence of platinum, rhodium or palladium indicates that the gold is not associated with the alluvial deposits of Yubdo (Wallaga) in Ethiopia (Molly, 1959).

With regard to the alloys (Table 2; Fig. 3), we observed that most of the artefacts were made from gold with a silver

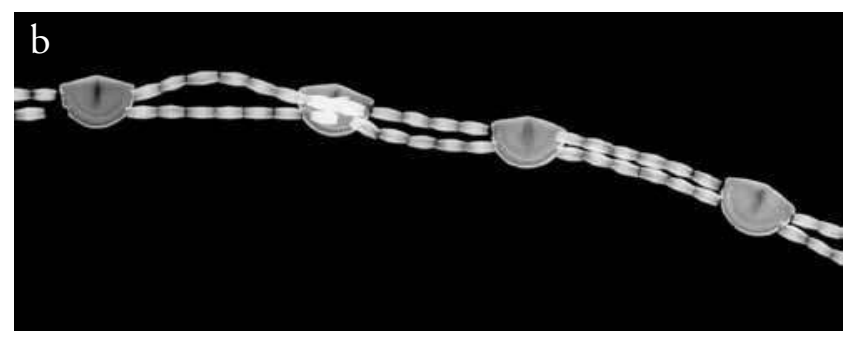

Figure 1: Qurneh girdle (A.1909.527.17): (a) OM image showing some deformation of barrel beads; (b) X-radiograph showing small barrel beads that have slipped inside a wallet bead.

Figure 1: Ceinture de Qurneh (A.1909.527.17): (a) image sous loupe binoculaire illustrant la déformation des perles coniques; (b) radiographie $X$ illustrant les petites perles coniques à l'intérieur d'une perle en portefeuille. 

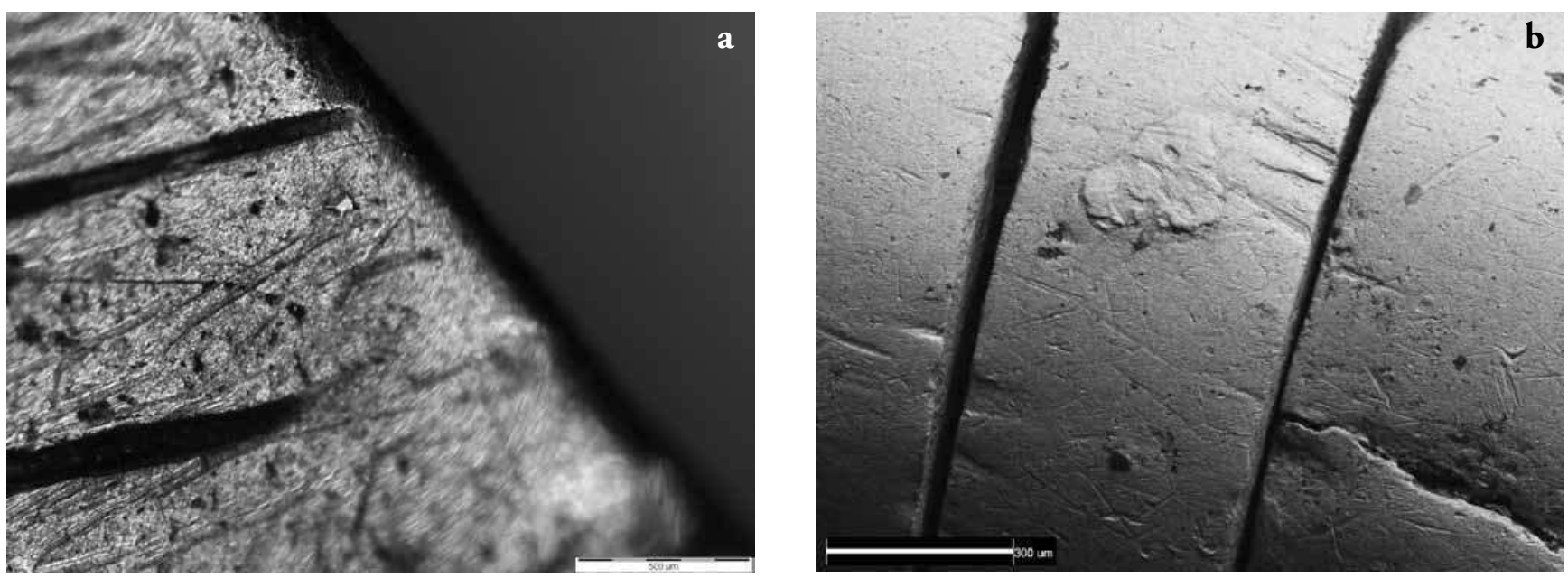

Figure 2: PGE inclusions in (a [See colour plate]) pendant (A.1914.1081) from el-Harāgeh by OM; (b) Qurneh child's necklace (A.1909.527.11) by SEI.

Figure 2 : (Voir planche couleur) Inclusions de platinö̈des (a [Voir planche couleur]) du pendantif (A.1914.1081) d'el-Harägeh sous loupe binoculaire; (b) du collier d'enfant de Qurneh (A.1909.527.11) au MEB.

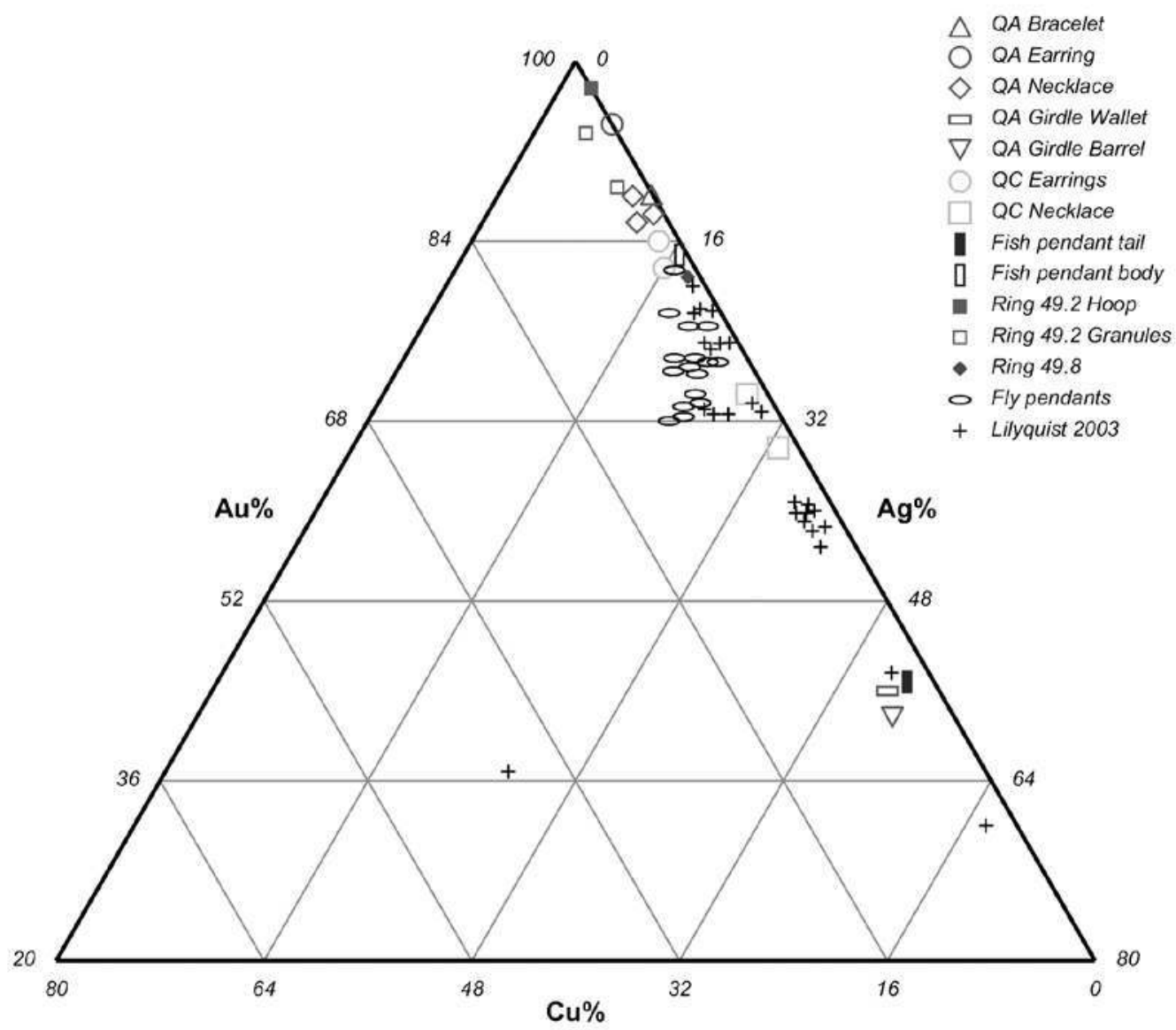

Figure 3: Ternary diagram (gold, silver, copper) showing the average alloy composition of the jewellery investigated (for some objects, multiple analyses of the different components were undertaken).

Figure 3 : Diagramme ternaire (or, argent, cuivre) montrant la composition moyenne des alliages des pièces d'orfevrerie analysées (pour certains objets l'analyse a été effectuée pour leurs différentes parties). 


\begin{tabular}{|c|c|c|c|c|}
\hline & & $\mathrm{Au} \%$ & $\mathrm{Ag} \%$ & $\mathrm{Cu} \%$ \\
\hline Qurneh & Adult's mummy (PIXE) & & & \\
\hline \multirow{2}{*}{$\begin{array}{l}\text { Bracelet A199-527-16 } \\
\text { standard deviation }\end{array}$} & & 88.2 & 11.6 & 0.3 \\
\hline & & 0.8 & 0.7 & 0.5 \\
\hline \multirow{2}{*}{$\begin{array}{l}\text { Earring adult A1909-527-18 } \\
\text { standard deviation }\end{array}$} & & 95.8 & 4.1 & 0.2 \\
\hline & & 1.0 & 0.9 & 0.1 \\
\hline \multirow{6}{*}{ Necklace A.1909.527.19 } & \multirow{2}{*}{$\begin{array}{l}\text { Ring 1 } \\
\text { standard deviation }\end{array}$} & 87.6 & 10.5 & 1.9 \\
\hline & & 1.6 & 1.6 & 0.1 \\
\hline & \multirow{2}{*}{$\begin{array}{l}\text { Ring } 2 \\
\text { standard deviation }\end{array}$} & 87.7 & 10.7 & 1.5 \\
\hline & & 1.1 & 0.9 & 0.2 \\
\hline & \multirow{2}{*}{\begin{tabular}{|l|} 
Ring 3 \\
standard deviation
\end{tabular}} & 88.0 & 10.0 & 2.0 \\
\hline & & 0.8 & 1.1 & 0.3 \\
\hline \multicolumn{5}{|l|}{ Girdle A.1909.527.17 } \\
\hline \multirow{4}{*}{$\begin{array}{l}\text { Average on } 26 \text { beads } \\
\text { Average on } 10 \text { beads }\end{array}$} & \multirow{2}{*}{$\begin{array}{l}\text { Wallet Beads (XRF) } \\
\text { standard deviation }\end{array}$} & 43.8 & 52.5 & 3.7 \\
\hline & & 0.3 & 0.3 & 0.1 \\
\hline & & 42.1 & 53.1 & 4.8 \\
\hline & standard deviation & 2.7 & 1.4 & 1.5 \\
\hline & Child's mummy (PIXE) & & & \\
\hline Earring A.1909.527.43 A & & 82.5 & 14.6 & 2.9 \\
\hline standard deviation & & 0.5 & 0.5 & 0.4 \\
\hline Earring A.1909.527.43 B & & 83.7 & 14.2 & 2.1 \\
\hline standard deviation & & 1.2 & 1.0 & 0.4 \\
\hline & Ring 1 & 71.3 & 26.8 & 2.0 \\
\hline Nertlace A 190952711 & standard deviation & 1.4 & 1.4 & 0.1 \\
\hline Necklace A.1909.52/.11 & Ring 2 & 65.9 & 32.1 & 2.0 \\
\hline & standard deviation & 0.6 & 0.8 & 0.2 \\
\hline Fish pendant A.1914.1081 & (XRF) & & & \\
\hline & & 45.0 & 51.7 & 3.3 \\
\hline standard deviation & & 1.5 & 1.5 & 0.1 \\
\hline Body & & 82.6 & 16.3 & 1.1 \\
\hline standard deviation & & 1.1 & 1.0 & 0.2 \\
\hline Amarna Rings & A.1883.49.2 & & & \\
\hline Hoop (XRF) & & 98.2 & 1.7 & 0.1 \\
\hline standard deviation & & 0.1 & 0.2 & 0.1 \\
\hline & Low row & 89.4 & 7.9 & 2.8 \\
\hline Granules (SEM-EDS) & standard deviation & 1.0 & 1.3 & 0.4 \\
\hline & Upper row & 94.0 & 3.3 & 2.7 \\
\hline & standard deviation & 1.3 & 0.9 & 0.4 \\
\hline & A.1883.49.8 (XRF) & 81.1 & 18.1 & 0.8 \\
\hline & & 0.6 & 0.5 & 0.1 \\
\hline Fly-shaped pendants 19th D & (XRF) & Sing & $\begin{array}{l}\text { nalysis } \\
\text { pendant }\end{array}$ & each \\
\hline A.1977.140.A & & 74.3 & 21.7 & 4.0 \\
\hline A.1977.140.B & & 70.5 & 23.4 & 6.1 \\
\hline A.1977.140.C & & 67.8 & 23.3 & 8.9 \\
\hline A.1977.140.D & & 74.3 & 19.7 & 6.0 \\
\hline A.1977.140.E & & 77.4 & 19.9 & 2.7 \\
\hline A.1977.140.F & & 68.2 & 23.5 & 8.2 \\
\hline A.1977.140.G & & 74.7 & 21.6 & 3.7 \\
\hline A.1977.140.H & & 74.5 & 21.7 & 3.9 \\
\hline A.1977.140.I & & 73.9 & 19.6 & 6.5 \\
\hline A.1977.140.J & & 81.8 & 16.2 & 1.9 \\
\hline A.1977.140.K & & 71.5 & 22.9 & 5.6 \\
\hline A.1977.140.L & & 72.3 & 22.6 & 5.1 \\
\hline A.1977.140.M & & 68.7 & 22.6 & 8.7 \\
\hline A.1977.140.N & & 77.9 & 18.3 & 3.8 \\
\hline A.1977.140.O & & 76.8 & 21.4 & 1.8 \\
\hline A.1977.140.P & & 73.0 & 22.3 & 4.7 \\
\hline Solder & & & & \\
\hline Qurneh & Adult's mummy (PIXE) & & & \\
\hline Bracelet A.1909.527.16 & & 84 & 10 & 6 \\
\hline standard deviation & & 3 & 1 & 3 \\
\hline Earring adult A.1909.527.18 & & 93 & 5 & 2 \\
\hline standard deviation & & 1 & 2 & 0 \\
\hline Necklace A.1909.527.19 & Ring & 87 & 9 & 4 \\
\hline & standard deviation & 3 & 2 & 0 \\
\hline & Terminal Part (XRF) & 80 & 15 & 5 \\
\hline & Child's mummy (PIXE) & & & \\
\hline Earring A.1909.527.43 A & & 81 & 12 & 7 \\
\hline standard deviation & & 0 & 1 & 1 \\
\hline Earring A.1909.527.43 B & & 84 & 9 & 7 \\
\hline Amarna Rings & A.1883.49.2 & & & \\
\hline Granules (SEM-EDS) & Low row & 83 & 9 & 8 \\
\hline & standard deviation & 5 & 2 & 4 \\
\hline & Upper row & 86 & 9 & 5 \\
\hline & standard deviation & 3 & 3 & 2 \\
\hline
\end{tabular}

content ranging from 2 to $20 \%$. The exceptions from the Qurneh burial are made of electrum, as defined by Pliny, i.e. a gold alloy in which the silver content is greater than $20 \%$ (Natural History, XXXIII): in the girdle, the silver content reaches $52.5-53 \%$ in the wallet beads and the barrel beads, and in the child's necklace, the silver content varies between 27 and $32 \%$. The tail of the Harāgeh pendant is also made of electrum containing $51.7 \%$ silver. Therefore, variation in alloys does not seem to be linked to chronology, but rather to type and presumably use of the objects, as well as perhaps to colour (Schorsch, 2001; Frantz and Schoesch, 1990), considering that the Egyptian words for gold (noub) and silver (hat) are colour-oriented.

Copper is generally present in quantities of less than $2 \%$; however, some objects exhibit a copper content higher than $3 \%$. The wallet beads of the Qurneh girdle contain 3.7\% copper, while in the barrel beads the copper content varies from 2.8 to $7.4 \%$. We found $3.3 \%$ copper in the tail of the fish-pendant, and, finally, the fly-pendants exhibit up to $9 \%$ copper. It seems unusual for Egyptian gold deposits to contain more than 2\% copper (Ogden, 2000), so most of the jewellery could have been manufactured using native alloys. For the wallet and barrel beads of the girdle, and the tail of the pendant, copper in the range of a few percent could have been added to a silver-rich electrum alloy. For the fly-pendants, the alloys could have been produced by adding copper to a native alloy with a relatively high silver content of $25 \%$ (such as the one that is found, for example, in the Qurneh child's necklace). The addition of copper to debase gold is usually reported from the $18^{\text {th }}$ Dynasty onwards, with copper-contents reaching $75 \%$ in some artefacts (Lucas, 1962: 229; Ogden, 2000). However, the amount of copper found in the barrel beads of the girdle clearly indicates that this process was in use since the $17^{\text {th }}$ Dynasty.

The Qurneh adult jewellery forms a specific group in Figure 3 , with a relatively high gold content ranging between $87.8 \%$ and $95.2 \%$. The child's earrings show a similar composition, with $82.5 \%$ and $83.7 \%$ gold, but with a higher level of copper, which may indicate an addition meant to harden the alloy. According to Ogden (2000), Egyptian gold during the $2^{\text {nd }}$ millennium BC typically contained $15-30 \%$ silver and copper in amounts lower than $2 \%$, while the use of the cementation method to refine gold was not practised there before the $1^{\text {st }}$ millennium BC (Ramage and Craddock, 2000).

Table 2: Compositional results (in wt $\%$ ) for all the objects analysed by PIXE, XRF and SEM-EDS.

Tableau 2 : Compositions (en \%) des alliages des objets analysés par PIXE, FX et MEB-EDS. 
Such expected compositions were identified in the Qurneh child's necklace, the Harāgeh pendant, and one of the Amarna finger-rings (A.1883.49.8), as well as in published jewellery from the tomb of the foreign wives of Thutmose III (Lilyquist, 2003). Indeed, Lilyquist (2003) argues that, in the collections of the Metropolitan Museum, only forgeries have alloys with gold content above $80 \%{ }^{4}$. Nevertheless, three of four items analysed from the tomb of Yuia and Tjuiu (Tomb KV46, early $14^{\text {th }}$ century BC) are at least $82 \%$ gold (Lucas 1962: 545), and one contains $96.4 \%$ gold, $1.9 \%$ silver, and less than $1 \%$ copper (Lucas 1962: 545) . At NMS, the Qurneh woman's earrings contain $95.6 \%$ gold, $4.1 \%$ silver and $0.2 \%$ copper $^{6}$, while one Amarna finger-ring (A.1883.49.2) contains 98.2\% gold, $1.7 \%$ silver and $0.1 \%$ copper. Such analyses indicate that Ancient Egyptians had access to gold of exceptional purity, either from alluvial deposits, or by importing from abroad (James, 1992). With regard to the Qurneh jewellery, at least, Nubian gold must be considered a possibility, because the burial itself shows definite cultural links with Nubia (Eremin et al., 2000; Manley et al., 2002). However, without further studies of contemporary objects, we cannot establish specific provenances for the placer gold used to manufacture the jewellery.

\section{Solder Analysis}

There are but few published analyses of solders from Egyptian jewellery, with the exception of the study of a necklace from the burial of Wah, dated to the late $11^{\text {th }}$ Dynasty (Schorsch, 1995), and of some objects dated to the $18^{\text {th }}$ Dynasty (Lilyquist, 2003). The common joining technique in Ancient Egypt might have been colloidal hard soldering (or diffusion bonding), using a copper salt and organic adhesive. Hard soldering using an alloy with a lower melting point than that of the alloy to be soldered (Maryon, 1949) is considered less usual (Ogden, 1992; Lilyquist, 2003). However, on beads from the Wah burial, Schorsch (1995) found an atypical joining technique, perhaps involving hard soldering by adding different amounts of copper to the basic alloy; and the investigation of a ring from the Qurneh necklace has shown the use of a hard solder alloy made by adding copper (Tate et al., 2009).

Distinguishing between different soldering techniques is difficult when using only non-invasive analyses. However, the

4. In some apparent instances of forgery, the gold composition is exactly 22 carat, corresponding to English gold coinage from the early $20^{\text {th }}$ century (Lucas 1962; Lilyquist 2003).

5. Compositions from assay analysis by W.B. Pollard (1908).

6 . These new analyses confirm the surface analysis undertaken by Eremin et al. (2000).
Qurneh jewellery clearly exhibits the use of hard soldering in the fabrication of the adult's gold earrings and bracelets, and of the child's earrings, as well as the necklace. The child's earrings seem to be melted from over-heating while hard soldering to create joins between the different rings (Fig. 4a); Petrie also noted that they "had been over-heated while on a mandril in the furnace for soldering; the solder had stuck them together, and they parted and began to drop away, being half melted" (Petrie, 1909). PIXE analyses of the soldered area show an increase in the copper content to $7 \%$, with a silver content of $12 \%$. In the soldered area of the adult's bracelets, the copper level reached $6 \%$, with $10 \%$ silver (Table 2 ).

The XRF investigation of the terminal part of the Qurneh necklace gave an estimate of $80 \%$ gold, $15 \%$ silver and 5\%
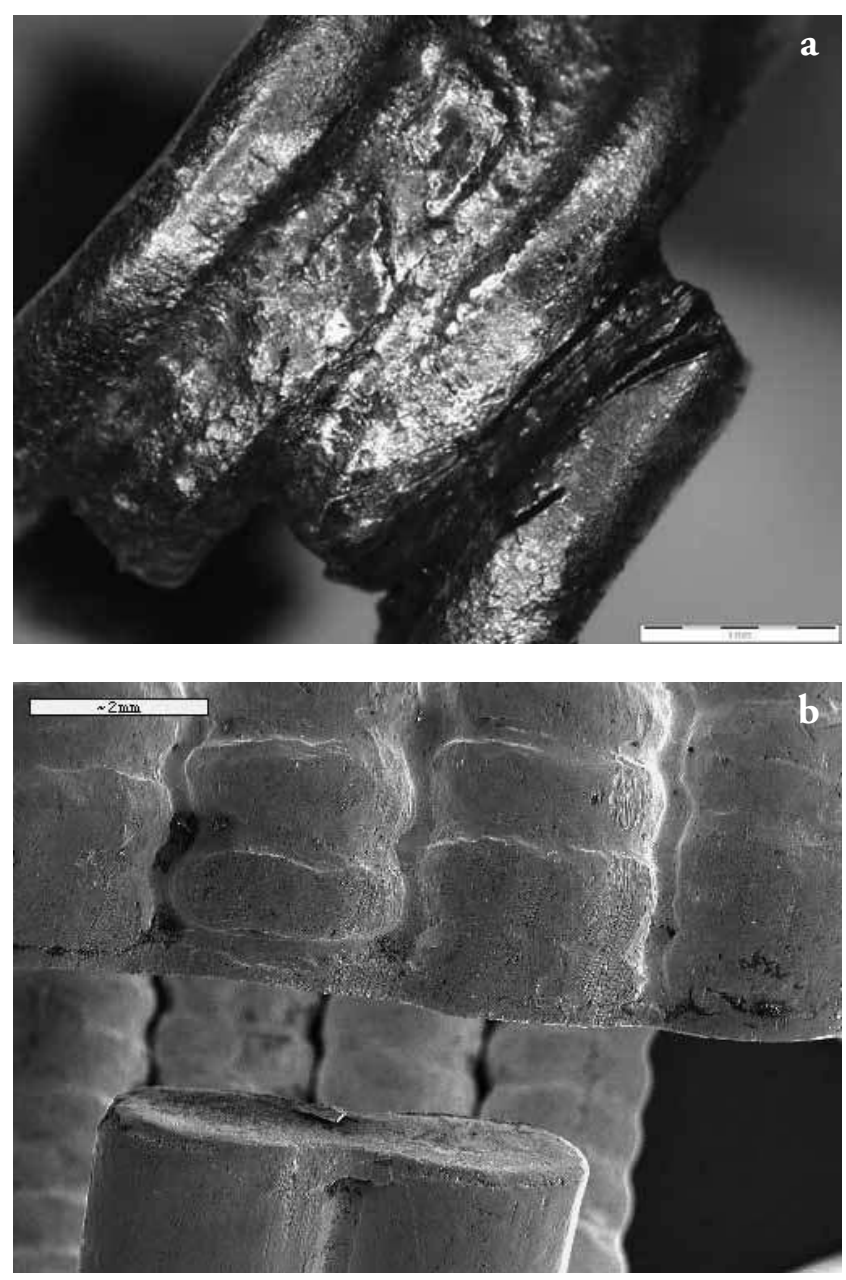

Figure 4: Detail of solder in (a [See colour plate]) Qurneh child's earring (A.1909.527.43) by OM and (b) Qurneh adult's earrings (A.1909.527.18) by SEI.

Figure 4 : Détail de la soudure des boucles d'oreilles de Qurneh (a [Voir planche couleur]) de l'enfant (A.1909.527.43) sous loupe binoculaire; (b) de l'adulte (A.1909.527.18) au MEB. 
copper. The PIXE investigation of the solder between the tubes of the adult's earrings indicated about $2 \%$ more copper than for the main body (Table 2). All these compositions correspond to a natural alloy with a fusion temperature slightly lower than the composition of the objects (Scott 1990), as is the case with the hard soldering of the beads of the necklace (Tate et al., 2009).

\section{Granulation}

Granulation is obtained by joining spheres to a metal sheet using hard soldering techniques or copper salt (Lilyquist, 1993). One of the first examples of granulated objects in Egypt is a gold cylinder-pendant, also from el-Harāgeh, which shows the use of hard soldering (Ogden, 1992). A similar morphology in the joining areas is found for the granules of an Amarna finger-ring (A.1883.49.2), details of which can be seen in Figure 5. EDS surface analysis of the granules showed that they are heterogeneous in composition (top: $2.8 \%$ copper, $7.9 \%$ silver, $89.4 \%$ gold; bottom: $2.7 \%$ copper, $3.3 \%$ silver, $94.0 \%$ gold). Although these compositions are unlikely to correspond to the sulk composition - due to surface enrichments this could indicate a decoration undertaken in two stages. Experimentally, it is difficult to obtain an accurate quantitative analysis on such three-dimensional objects, which is probably the reason for the high variability of copper and silver analyses in the soldered areas. However, the indication is that in the top row, the copper content ranges from 5 to $13 \%$, and silver

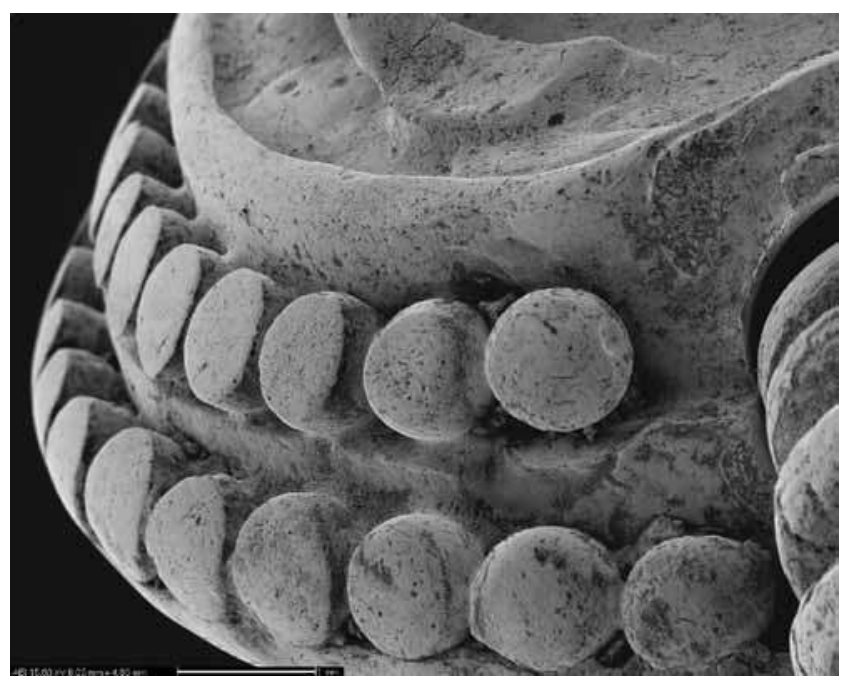

Figure 5: Detail of granulation observed on the bezel of the fingerring A.1883.49.2 by SEI.

Figure 5: Détail de la granulation du chaton de la bague A.1883.49.2 au $M E B$. from 7 to $12 \%$, while in the bottom row the copper content ranges from 4 to $7 \%$, and silver from 6 to $11 \%$, which could indicate the use of separate hard solders in each row, with different melting points.

\section{Construction and wirework}

The Amarna finger-rings show a similar mounting technique, whereby a wire is coiled around the hoop and enters the bezel (Fig. 6a). This may be analogous to technology from late $5^{\text {th }}$ millennium Egypt, when rings could be made with "small strings of beads, gold-foil bands and wires of copper or silver closed by twisting the ends together" (Andrews, 1990).

In the case of finger-ring A.1883.49.8, the round section of the hoop is reduced, and has been worked into a wire that crosses the bezel and is coiled upon each extremity. In the case of finger-ring A.1883.49.2, a much thicker hoop has been worked at the terminals into a thinner section and passed through the bezel, while, in addition, a wire is coiled round the hoop, crossing the bezel. Similar techniques may be seen in finger-rings in the British Museum (Andrews, 1991: 164-165, 175) and necklaces from the burial of the foreign wives of Thutmose III (Lilyquist, 2003: 196).

Hammering, block-twisting, strip-drawing and striptwisting have all been suggested as possible techniques for producing wires in antiquity (Oddy, 1977). Although no specific work published on Ancient Egyptian wires exists, hammering was usual in Bronze Age jewellery according to Petrie, strip-drawing was identified by Williams (1924), although this has been significantly questioned, while striptwisting was largely discussed by Carroll (1972). As regards Ancient Egyptian objects, Williams (1924) suggests the use of strip-drawing and strip-twisting, while Scheel (1989) suggests that thick wires were produced by strip-twisting and thinner wires by block-twisting. Hammered wire presents facetted surfaces; block-twisted wire has a more or less round section with a solid interior; while both strip-drawing and strip-twisting result in a round section wire with a hollow interior (Oddy, 1977).

For the Amarna finger-rings, we identified the following characteristics: the wire of A.1883.49.2 is relatively thick, with a section that is solid but sometimes not circular, whereas the wire of A.1883.49.8 is solid, rounder in section, and shows some longitudinal lines. In the wires of both rings, we observed flaking and overlapping of gold, possibly corresponding to rolling and burnishing treatments (Fig. 6b). Excluding the effects of wear, we observe a homogeneous wire with a near round section and seams on the surface similar to those produced by strip-twisting. Further examination of the wires is in progress at the NMS in order 

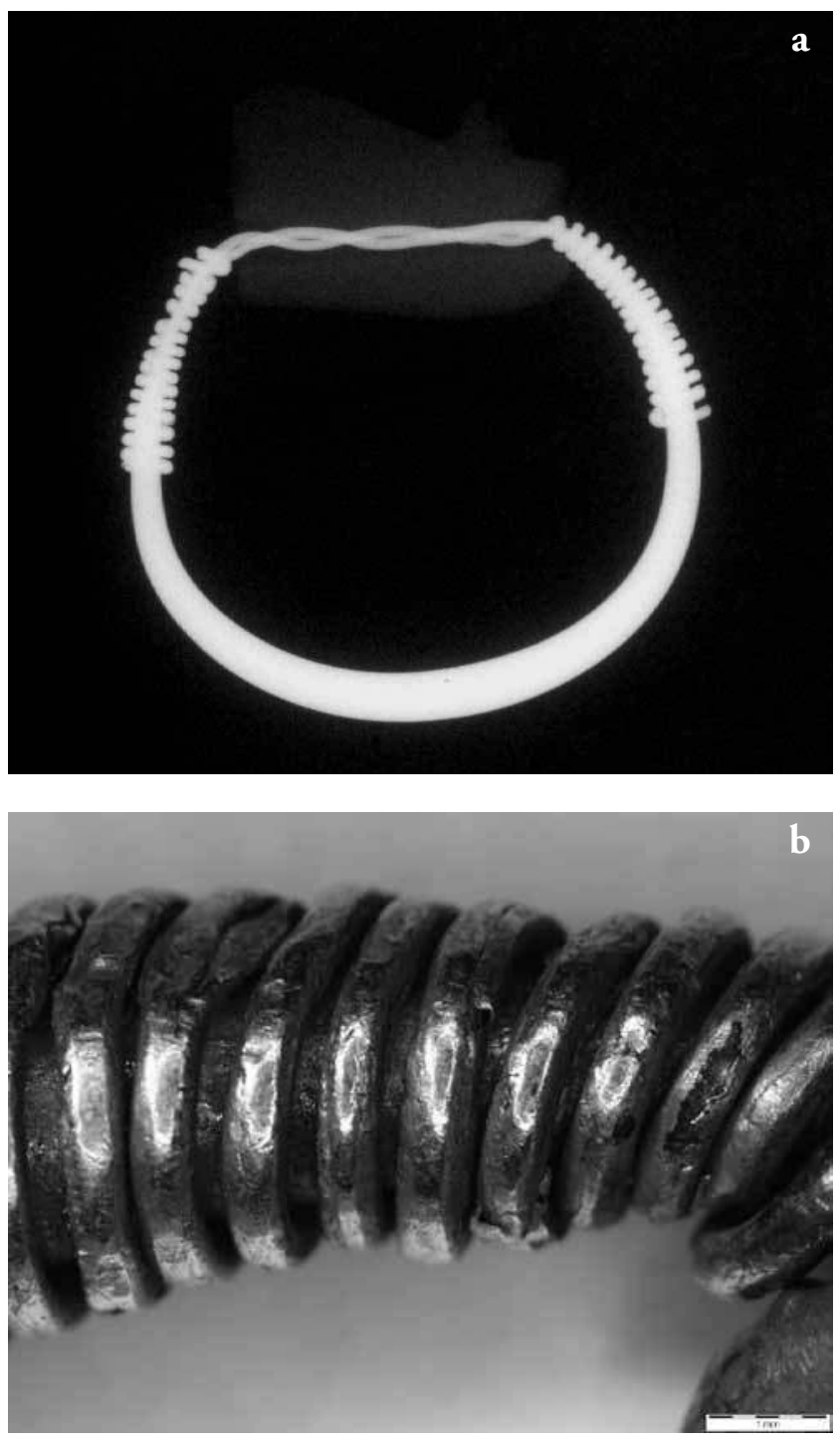

Figure 6: Amarna finger-rings: (a) X-Radiograph of A.1883.49.8 showing the construction of the bezel and (b) detail of A.1883.49.2 showing the work of the wire coiled upon each end of bezel.

Figure 6 : Bagues d'Amarna: (a) radiographie X de A.1883.49.8 montrant le montage du chaton et (b) détail de A.1883.49.2 illustrant le travail du fil enroulé autour de l'anneau de chaque côté du chaton.

to verify whether the same techniques were generally used throughout the $17^{\text {th }}$ and $18^{\text {th }}$ Dynasties.

\section{Conclusion}

This study represents a first approach to the production techniques of Egyptian gold jewellery by presenting results obtained for a group of items from the collections of the NMS, dated to a period between the $19^{\text {th }}$ and the $13^{\text {th }}$ cen- turies BC. We have shown that the gold alloys used during this period are preponderantly produced with alluvial gold containing iridium-ruthenium-osmium inclusions. The alloys used to produce the studied jewellery range from high purity ones, with a gold content that can reach $95 \%$, to electrum containing 51 to $53 \%$ silver. Apart from objects in which copper was certainly added to the alloy, the copper content was typically found to be below $2 \%$. The use of filigree and granulation in the decoration of the Amarna finger-rings revealed the use of hard soldering, and traces of this technique were found in joints for the majority of the objects studied. The seams in the limited sample set of wires have sections that may indicate the use of strip-twisting.

\section{Acknowledgment}

The authors would like to thank colleagues at NMS, in particular Henrietta Lidchi and Lesley-Ann Liddiard from the World Cultures Department, for giving us access to the objects and supporting the project; colleagues at C2RMF, especially the AGLAE team and Thierry Borel for his help and advice on X-Radiography of gold objects; Katherine Eremin at the Harvard Art Museum for comments on her previous work; Susan La Niece and Nigel Meeks at the British Museum for their comments while writing the article, and finally the Eu-ARTECH project for funding the PIXE analysis.

\section{References}

AHmed, A.H., 2007. Diversity of platinum-group minerals in podiform chromitites of the late Proterozoic ophiolite, Eastern Desert, Egypt. Ore Geology Reviews 32: 1-19.

Andrews, C., 1990. Ancient Egyptian Jewellery. London, The British Museum Press.

Carroll, D.L., 1972. Wire drawing in Antiquity. American Journal of Archaeology 76(3): 321-323.

Dran, J.C., Salomon, J., Calligaro, T. and Walter, P., 2004. Ion beam analysis of art works: 14 years of use in the Louvre. Nuclear Instruments and Methods in Physics Research B 219220: 7-15.

Eremin, K., Goring, E., Manley, W.P. and Cartwright, C., 2000. A $17^{\text {th }}$ dynasty Egyptian Queen in Edinburgh? KMT Modern Journal of Egyptology 11(3): 32-40.

Frantz, J.H. and Schorsch, D., 1990. Egyptian Red Gold. Archeomaterials 4: 133-152.

Guerra, M.F., 2008. An overview on the ancient goldsmith's skill and the circulation of gold in the past; the role of $x$-ray based techniques. X-ray Spectrometry 37: 317-327. 
Guerra, M.F. and Calligaro, T., 2003. Gold cultural heritage objects: a review of studies of provenance and manufacturing technologies. Measurement Science and Technology 14: 15271537.

JAMES, T.G.H., 1972. Gold Technology in Ancient Egypt. Mastery of Metal working methods. Gold Bulletin 2(5): 35-42.

LiLyquist, C., 1993. Granulation and Glass: Chronological and Stylistic Investigations at Selected Sites, ca. 2500-1400 B.C.E. Bulletin of the American Schools of Oriental Research 290/291: 29-94.

LILYQUIST, C., 2003. The tomb of the three foreign wives of Tuthmosis III. New York, The Metropolitan Museum of Art.

LuCAS, A. and Harris, J.R., 1962. Ancient Egyptian Materials and Industries. London, Edward Arnold Publishers Ltd.

Manley, W.P., Eremin, K., Shortland, A. and Wilkinson, C., 2002. The facial reconstruction of an Ancient Egyptian Queen. Journal of Audiovisual Media in Medicine 25(4): 155159.

MarTin, G.T., 1974. The Royal Tomb at El-Amarna, I. The Objects. London: Egypt Exploration Society.

Maryon, H., 1949. Metal Working in the Ancient World. American Journal of Archaeology 53(2): 93-125.

Meeks, N.D. and Tite, M.S., 1980. The analysis of Platinumgroup Element inclusions in Gold Antiquities. Journal of Archaeological Science 7: 267-275.

Molly, E.W., 1959. Platinum deposits of Ethiopia. Economic Geology 54(3): 467-477.

ODDY, A., 1977. The production of gold wire in Antiquity. Handmaking methods before the introduction of the draw-plate. Gold Bulletin 3(10): 79-87.

Ogden, J., 1976. The so-called "platinum" inclusions in Egyptian goldwork. Journal of Egyptian Archaeology 62: 138-144.

Ogden, J., 1982. Jewellery of the Ancient world. London, Trefoil Books.
Ogden, J., 1992. Interpreting the past: Ancient Jewellery. London, The British Museum Press.

Ogden, J., 2000. Metals, in P.T. Nicholson, I. Shaw (eds.), Ancient Egyptian Materials and Technology. Cambridge, Cambridge University Press, 148-175.

Petrie, W.M.F., 1909. Qurneh. London: BSAE Publishing.

Pliny the Elder, Natural History, XXXIII, J. Bostock translation, London, Taylor and Francis.

Pollard, W.B., 1908. Gold, in J.E. Quibell (ed.), Tomb of Yuaa and Thuiu. Le Caire, Imprimerie de l'Institut français d'archéologie orientale, 77-78.

Ramage, A. and Craddock, P., 2000. King Croesus' Gold. Excavations at Sardis and the History of Gold Refining. London, British Museum Press.

Royal Museum Register of Specimens. Art and Ethnographical Department. Volume 11 (Eleven). 1908 - 1913 (1908.311 1913.401): 82

ScheEl, B., 1989. Egyptian Metalworking and Tools. Shire: Shire Egyptology, Shire Publications Ltd.

Schorsch, D., 1995. The gold and silver necklaces of Wah: a technical study of an unusual metallurgical joining method, in C. Brown, F. Macalister, M. Wright (eds.), Conservation in Ancient Egyptian Collections. London, Archetype Publications, 127-135.

Schorsch, D., 2001. Precious-Metal Polychromy in Egypt in the Time of Tutankhamun. Journal of Egyptian Archaeology 87: $55-71$.

Scott, D., 1990. Soldering with gold alloys in ancient South America. Archaeometry 32: 183-190.

Tate, J., Eremin, K., Troalen, L., Guerra, M.F., Goring, E. and Manley, W.P., 2009. The $17^{\text {th }}$ Dynasty Gold Necklace from Qurneh, Egypt. ArcheoSciences 33.

Williams, C.R., 1924. Catalogue of Egyptian Antiquities, Gold and Silver Jewelry and Related Objects. New York, The New York Historical Society. 
